\title{
Robert Dankiewicz
}

Rzeszow University of Technology

e-mail: robertdankiewicz@wp.pl

\section{INSURANCE GUARANTEES AS A TOOL TO SUPPORT RISK MANAGEMENT PROCEDURES IN AN ENTERPRISE}

\section{GWARANCJE UBEZPIECZENIOWE JAKO NARZĘDZIE WSPOMAGAJĄCE PROCESY ZARZĄDZANIA RYZYKIEM W PRZEDSIĘBIORSTWIE}

DOI: $10.15611 /$ nof.2017.4.04

JEL Classification: G22, G32

Summary: The subject of the article covers the issues related to the possibilities and conditions for the use of insurance guarantees in enterprise risk management processes. In the paper the essence of the guarantee process, its legal basis and the types of guarantees are discussed. The market for insurance guarantees in Poland is presented, with an attempt to refer to the market for guarantees offered by the banking sector. Based on the research conducted, the author presents the role and importance of insurance guarantees as a tool to support business processes in enterprises. The answers to the questions as to in what situations insurance guarantees are an effective tool to support these processes and what are the reasons behind their use are provided. The purpose of the publication is to analyze the role, significance and possibilities of using insurance guarantees as a tool to support risk management processes in the day-to-day operations of companies.

Keywords: insurance guarantee, risk management.

Streszczenie: Tematyka artykułu obejmuje zagadnienia dotyczące możliwości i przesłanek wykorzystania gwarancji ubezpieczeniowych $\mathrm{w}$ procesach zarządzania ryzykiem w przedsiębiorstwach. W opracowaniu omówiono istotę procesu gwarantowania, jego prawne podstawy oraz rodzaje gwarancji. Zaprezentowano rynek gwarancji ubezpieczeniowych w Polsce, podjęto próbę jego odniesienia do rynku gwarancji oferowanych przez sektor bankowy. W oparciu o przeprowadzone badania podjęto próbę prezentacji roli i znaczenia gwarancji ubezpieczeniowych jako narzędzia wspomagającego procesy zarządzania w przedsiębiorstwach. Udzielono odpowiedzi na pytania, w jakich sytuacjach gwarancje ubezpieczeniowe są skutecznym narzędziem wspomagającym omawiane procesy oraz jakie przesłanki przemawiają za ich wykorzystaniem. Celem autora artykułu jest analiza roli i znaczenia oraz możliwości wykorzystywania gwarancji ubezpieczeniowych jako narzędzia wspomagającego procesy zarządzania ryzykiem w bieżącej działalności przedsiębiorstw.

Słowa kluczowe: gwarancje ubezpieczeniowe, zarządzanie ryzykiem. 


\section{Introduction}

The practice of insurance guarantees spread in many countries, has also appeared in Poland. Initially, the admissibility of their granting against the provisions regulating insurance activity raised some doubts. The insurance guarantee, which is the guarantee of the performance of the obligation, has been still an unknown concept. It is, however, admitted that it is permissible on the basis of the principle of contractual freedom (articles 353, 391, 393 of the Civil Code) [The act of 23 April 1964 Civil Code], and has, therefore, largely been shaped by practice.

At the time of introduction, neither the Act on Insurance Activity nor the Civil Code contained any detailed rules regarding this issue. However, it is acceptable on the basis of the principle of contractual freedom. The above was resolved by the judgment of the Supreme Court of 16 April 1996 (No. II CRN 38/96), which stated that "the subject of insurance business conducted by insurance and reinsurance institutions under the Act of 28 July 1990 on insurance business may be also granting these facilities of self-contained, irrevocable, unconditional and payable on first request guarantees".

Currently, insurance guarantees are a commonly used tool in enterprise risk management processes as they reduce significantly uncertainty in the area of business activity by promising the insurance company to pay the guarantee sum when a beneficiary claims a justified claim. The uniqueness of the insurance guarantee arises from the fact that the payer in the product is not its beneficiary [Dankiewicz, Kaczmarczyk, Kidacka 2017], and the issue of a guarantee merely confirms its credibility, which becomes particularly useful in uncertain market situations.

Companies are increasingly inclined towards the market opportunities to minimize and manage the risks associated with their partners by using the guarantees offered by insurance companies in this process. Despite the large and constantly growing interest on the part of entrepreneurs, insurance guarantees are relatively rarely the subject of scientific research, which is reflected only in a few scientific publications in this field. The content presented in the vast majority of cases refers to the nature of the guarantee processes, legal basis, possibly taking into account the size of the market compared to other products. At present, the guarantees are of great importance in the ongoing economic processes. In the years preceding the 2008 crisis, which might be a subject of wider consideration, the increase in trade also led to the growth in the insurance guarantee market. Similarly it was during the crisis when the decline in global trade and the increased risk of business activity affected the contraction of the insurance guarantee market [Chauffour, Saborowski, Soylemezoglu 2011].

The purpose of the publication is to analyze the role, significance and possibilities of using insurance guarantees as a tool to support risk management processes in the day-to-day operations of companies. 


\section{The essence of the guarantee process}

The appearance of the guarantee institution is related to the uncertainty that accompanies entities participating in economic transactions. Uncertainty consists, among other things, in the fact that the trader is not able to predict how the counterparties with which they enter into contracts will behave. Of course, to some extent the behavior of contractors is predictable, especially when cooperation with them has been ongoing for some time, but the risk element always remains. This is the greater the more the environment in which the business operates is subject to change. In any contractual relationship, the creditor is exposed to the risk of injury as a result of the debtor's failure or improper performance [Kukiełka, Poniewierka 2003]. It has many forms of hedging, including, among others, insurance guarantees.

The term 'guarantee' is defined as the type of contractual obligation incurred by the person acting as the guarantor towards the beneficiary of the guarantee for a certain behavior in the case when the expected event does not occur. The guarantee relationship is trilateral, involving the guarantor, the obligee and the beneficiary of the guarantee. The guarantee relationship is based on a binding contract, which is a part of a group of contracts that provide a hedging function. The parties to the guarantee contract are the guarantor and the beneficiary of the guarantee. The guarantee agreement can be concluded by any legal entity having legal capacity, including the insurer, on the basis of general freedom (Articles 66-72 of the Civil Code). The insurance guarantee agreement obliges the guarantor to pay a specified amount of money (guarantee amount) in the case of a non-originating event within the meaning of Art. $805 \S 2$ and Art. $822 \S 1-5$ of the Civil Code. The obligation to pay the guarantee sum arises only when the circumstances specified in the guarantee appear [Andrzejuk, Heropolitańska 2007]. In the case of payment of the guarantee sum, the insurance company is entitled to a recourse claim for reimbursement of this sum to the principal [Gurgul 2014].

In addition to securing the creditor's interest, the purpose of issuing the guarantee is to confirm the debtor's credibility, thereby gaining credibility in the creditor's eyes [Holly 2003]. In addition, the benefits of the guarantee include: the assurance and effectiveness, ease of enforcement and the speed of beneficiary's receipt of insurance from an insurance company and the virtually unlimited supply of guarantee services by one insurance company [Dankiewicz 2005]. One of the main advantages of applying guarantees in business is improving the liquidity of an enterprise. This is because of two reasons: the guarantee company avoids engaging its own funds to provide the collateral required by the counterparty, and if prior collateral is provided in cash, the presentation of the guarantee offers the possibility of unlocking financial collateral submitted to previously concluded contracts [Jańska 2013]. In relation to the insurance guarantee obligation, there are usually three entity relations [Jańska 2013]:

- the basic relation between the beneficiary of the guarantee (the guarantor and the beneficiary of the guarantee) with the debtor obliged to perform the performance secured by the guarantee, 
- the relation of the guarantee order (referred to as the coverage relation) that connects the guarantor with the principal's debtor, i.e. the principal; the source of this relation is the contract in which the guarantor commits himself/herself for a reasonable fee, called a commission, to provide a creditor with a basic relation,

- the relation of the guarantee with the guarantor and the principal from the statutory contract concluded by the guarantor in the form of the guarantee.

The guarantee text is subject to negotiation between the beneficiary and the guarantor, often through the obligee. The applicable law has never introduced any warrant or restriction in this regard. The problem faced by insurance companies is the lack of understanding by the applicants of how strongly this element affects the risks involved. They treat the terms and conditions of the insurer with respect to the acceptable guarantee text as proof of the non-market approach to customer's needs and lack of innovation [Poniewierka 1997]. With this type of activity insurance companies get an additional service that they often do not even notice. This is a professional analysis of not only the proposed guarantee text, but also the terms of the contract that is the source of the secured liability.

Taking into account that insurance guarantees can secure the performance of various obligations, their catalogue is an open set that can be continuously extended. In practice, however, with certain types of guarantees we encounter much more often, others most often occur in theoretical terms. On the Polish market the most frequently encountered are: contract guarantees (payment of the bid bond, performance of the contract, removal of defects and failures, performance of the contract, deposit repayment), guarantee payments (contractual receivables, construction works), guarantee of customs and excise duties, concessions and bail guarantees.

\section{Directions of changes in the insurance guarantee market}

Insurance guarantees like all other financial insurance products in Poland have a short history compared to highly developed markets. Initially about $80 \%$ of the Polish insurance market was covered by insurance guarantees, whose percentage share in total gross premiums of the second division in 1994-2005 increased from $0.27 \%$ to $0.89 \%$. In the years $2013-2015$ it was already $1.34 \%, 1.39 \%$ and $1.30 \%$, respectively. In the market one can notice the stable level of the number of insurance bidders which fluctuated between 23 and 25 insurers in the last five years. A list of insurance companies offering insurance guarantees in Poland is presented in Table 1.

The insurance guarantee market, similar to the insurance market, is liable to 'boom' changes. Declines due to constraints on the part of bidders arise when the number of payers who do not repay their obligations is increasing. Often, their solvency problems may be related to the overall market declines caused by the recession. It is difficult to manage risk effectively at this time, because it is impossible to predict accurately future economic realities for several years ahead. The changes taking place on the market of insurance guarantees in Poland are presented in Table 2. 
Table 1. Insurance companies offering insurance guarantees in Poland in 2011-2016

\begin{tabular}{|c|c|c|c|c|c|c|}
\hline Specification & 2016 & 2015 & 2014 & 2013 & 2012 & 2011 \\
\hline TUiR ALLIANZ POLSKA S.A. & $\mathrm{x}$ & $\mathrm{x}$ & $\mathrm{x}$ & $\mathrm{x}$ & $\mathrm{x}$ & $\mathrm{x}$ \\
\hline AVIVA TU OGÓLNYCH S.A. & & $\mathrm{x}$ & $\mathrm{x}$ & $x$ & $x$ & $\mathrm{x}$ \\
\hline AXA UBEZPIECZENIA TUiR S.A. & $\mathrm{x}$ & & & & & \\
\hline AXA TUiR S.A. & $\mathrm{x}$ & $\mathrm{x}$ & $\mathrm{x}$ & $\mathrm{x}$ & $\mathrm{x}$ & $\mathrm{x}$ \\
\hline AXA UBEZPIECZENIA TUiR S.A. & & $x$ & & & & \\
\hline BENEFIA TU S.A. Vienna Insurance Group & & & $\mathrm{x}$ & $\mathrm{x}$ & $\mathrm{x}$ & $\mathrm{x}$ \\
\hline BRE UBEZPIECZENIA TUiR S.A. & & & $x$ & $x$ & $\mathrm{x}$ & $\mathrm{x}$ \\
\hline COMPENSA TU S.A. Vienna Insurance Group & $\mathrm{x}$ & $\mathrm{x}$ & $\mathrm{x}$ & $\mathrm{x}$ & $\mathrm{x}$ & $\mathrm{x}$ \\
\hline CONCORDIA POLSKA TUW & $\mathrm{x}$ & $\mathrm{x}$ & $\mathrm{x}$ & $\mathrm{x}$ & $\mathrm{x}$ & $\mathrm{x}$ \\
\hline STU ERGO HESTIA SA & $\mathrm{x}$ & $\mathrm{x}$ & $\mathrm{x}$ & $\mathrm{x}$ & $\mathrm{x}$ & $\mathrm{x}$ \\
\hline TU EULER HERMES S.A. & $\mathrm{x}$ & $\mathrm{x}$ & $\mathrm{x}$ & $\mathrm{x}$ & $\mathrm{x}$ & $\mathrm{x}$ \\
\hline TU EUROPA S.A. & $\mathrm{x}$ & $\mathrm{x}$ & $\mathrm{x}$ & $\mathrm{x}$ & $\mathrm{x}$ & $\mathrm{x}$ \\
\hline GENERALI T.U. S.A. & $\mathrm{x}$ & $\mathrm{x}$ & $\mathrm{x}$ & $\mathrm{x}$ & $\mathrm{x}$ & $\mathrm{x}$ \\
\hline GOTHAER TU S.A. & $\mathrm{x}$ & $\mathrm{x}$ & $\mathrm{x}$ & $\mathrm{x}$ & $\mathrm{x}$ & $\mathrm{x}$ \\
\hline TU INTER POLSKA S.A. & $\mathrm{x}$ & $\mathrm{x}$ & $\mathrm{x}$ & $\mathrm{x}$ & $\mathrm{x}$ & $\mathrm{x}$ \\
\hline INTERRISK S.A. Vienna Insurance Group & $\mathrm{x}$ & $\mathrm{x}$ & $\mathrm{x}$ & $\mathrm{x}$ & $\mathrm{x}$ & $\mathrm{x}$ \\
\hline KUKE S.A. & $\mathrm{x}$ & $\mathrm{x}$ & $\mathrm{x}$ & $\mathrm{x}$ & $\mathrm{x}$ & $\mathrm{x}$ \\
\hline LINK4 TU S.A. & & $\mathrm{x}$ & $\mathrm{x}$ & $\mathrm{x}$ & $\mathrm{x}$ & $\mathrm{x}$ \\
\hline TUW MEDICUM & $\mathrm{x}$ & & & & & \\
\hline TUiR PARTNER S.A. & $\mathrm{x}$ & $\mathrm{x}$ & $\mathrm{x}$ & $\mathrm{x}$ & $\mathrm{x}$ & $\mathrm{x}$ \\
\hline PKO TU S.A. & $x$ & & & & & \\
\hline T.U.W. POCZTOWE & $\mathrm{x}$ & $\mathrm{x}$ & $\mathrm{x}$ & $\mathrm{x}$ & $\mathrm{x}$ & $\mathrm{x}$ \\
\hline PTR S.A. & & & & & & $\mathrm{x}$ \\
\hline PTU S.A. & & & & & & $\mathrm{x}$ \\
\hline $\begin{array}{l}\text { TUW POLSKI ZAKŁAD UBEZPIECZEŃ } \\
\text { WZAJEMNYCH }\end{array}$ & $\mathrm{x}$ & & & & & \\
\hline PZU SA & $\mathrm{x}$ & $\mathrm{x}$ & $\mathrm{x}$ & $\mathrm{x}$ & $\mathrm{x}$ & $\mathrm{x}$ \\
\hline SIGNAL IDUNA POLSKA TU S.A. & $\mathrm{x}$ & $\mathrm{x}$ & $\mathrm{x}$ & $\mathrm{x}$ & $\mathrm{x}$ & $\mathrm{x}$ \\
\hline TUW TUW & $\mathrm{x}$ & $\mathrm{x}$ & $\mathrm{x}$ & $\mathrm{x}$ & $\mathrm{x}$ & \\
\hline TUZ TUW & $\mathrm{x}$ & $\mathrm{x}$ & $\mathrm{x}$ & $\mathrm{x}$ & $\mathrm{x}$ & $\mathrm{x}$ \\
\hline UNIQA TU S.A. & $x$ & $\mathrm{x}$ & $\mathrm{x}$ & $\mathrm{x}$ & $\mathrm{x}$ & $\mathrm{x}$ \\
\hline TUiR WARTA S.A. & $\mathrm{x}$ & $\mathrm{x}$ & $\mathrm{x}$ & $\mathrm{x}$ & $\mathrm{x}$ & $\mathrm{x}$ \\
\hline
\end{tabular}

Source: own research based on Polish Financial Supervision Authority. 
Changes in the degree of the use of insurance guarantees in Poland over the past three years are reflected in the world markets, especially due to the good situation on the construction market. In developed countries, the current infrastructure needs modernization and is growing and developing all the time, which is a positive sign for the market. At the same time, the guarantee market has for some time been a market of growing profitability with optimistic prospects for the future. However, it is important to remember that this market depends on public and private sector clients focused on infrastructure and construction-related sectors, and on external factors such as public investment, interest rates and raw material prices [Schmidt 2017].

Table 2. Trends of insurance market changes in Poland in 2005-2016

\begin{tabular}{|l|r|r|r|r|r|r|r|r|r|r|r|r|}
\hline \multicolumn{1}{|c|}{ Specification } & 2005 & 2006 & 2007 & 2008 & 2009 & 2010 & 2011 & 2012 & 2013 & 2014 & 2015 & 2016 \\
\hline $\begin{array}{l}\text { Gross written } \\
\text { premium (mln PLN) }\end{array}$ & 136,1 & 150,2 & 187,0 & 215,0 & 50,4 & 318,0 & 302,8 & 274,7 & 294,6 & 347,2 & 356,8 & 336,3 \\
\hline $\begin{array}{l}\text { Gross claims ratio } \\
\text { (mln PLN) }\end{array}$ & 49,1 & 56,7 & 18,4 & 21,1 & 59,4 & 50,4 & 66,7 & 422,6 & 329,5 & 178,5 & 118,3 & nd \\
\hline Gross claims ratio (\%) & 36,0 & 37,8 & 9,8 & 9,8 & 117,7 & 15,9 & 22,0 & 153,9 & 111,8 & 51,4 & 33,2 & nd \\
\hline
\end{tabular}

nd - no data.

Source: own research based on the Polish Financial Supervision Authority.

There is a growing demand for international insurance guarantees, which often prove to be a good alternative to banks, and in some cases also cheaper [Schmidt 2017] (partly because of the requirements imposed on banks by Basel III, as a result of which they partially withdraw from the guarantee offer).

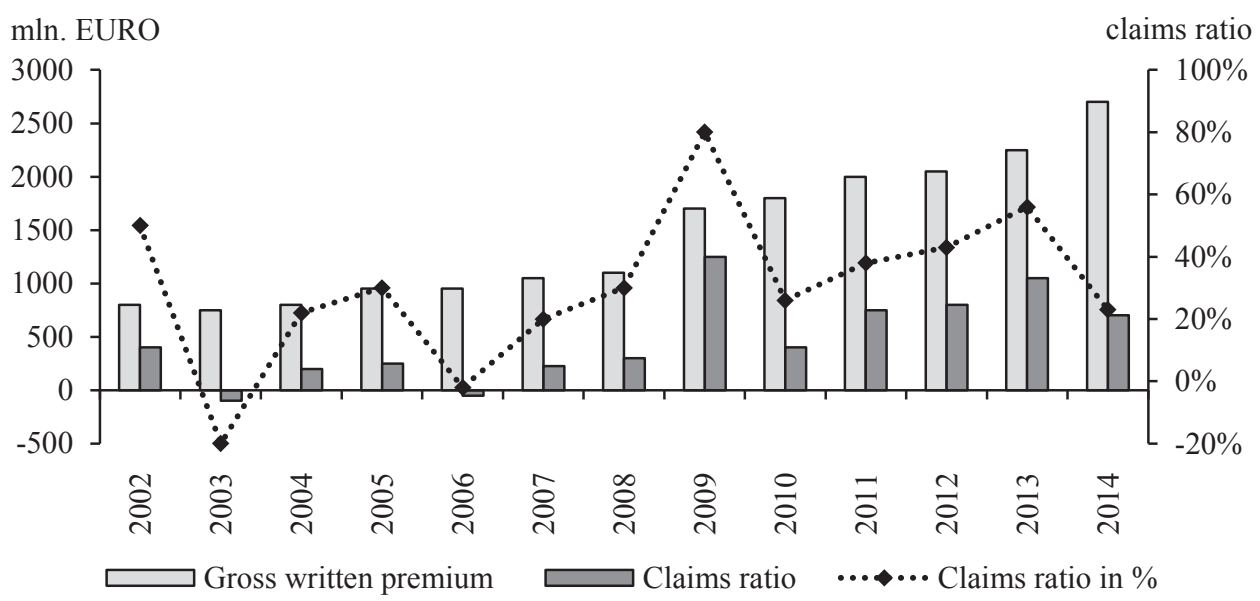

Fig. 1. Gross written premiums and claims ratio among ICISA members in 2002-2014

Source: own research based on [Schmidt 2017, p. 7]. 
The largest potential market for insurance guarantees in the world exists in the United States, which accounts for $40 \%$ of the global premium, i.e. $\$ 5,3$ billion, and they play a significant role in the Mexican economy. In Asia, the strongest growth was in South Korea, where the premiums written equal $\$ 1,4$ billion. The trends of changes in world markets in the analyzed area are presented in Figure 1.

Insurance guarantees are competing products in relation to bank guarantees. In the United States the role of banks in this area is severely limited by legal regulations as opposed to Europe where banks have a dominant position [Schmidt 2017]. A similar situation is also observed in the Polish economy, but there is no consolidated source of data to allow a comparison of the insurance and banking market in the analyzed area. Source data with respect to the insurance market refers to the premiums written, whereas in the case of the banking market, the amount of guarantees is covered. The amount of guarantees granted by the banking sector is presented in Table 3.

Table 3. Market size of bank guarantees in Poland in 2011-2015

\begin{tabular}{|l|r|r|r|r|r|}
\hline \multicolumn{1}{|c|}{ Specification } & \multicolumn{1}{c|}{2011} & \multicolumn{1}{c|}{2012} & \multicolumn{1}{c|}{2013} & \multicolumn{1}{c|}{2014} & \multicolumn{1}{c|}{2015} \\
\hline Amount of guarantees granted (in mln PLN) & 50600,00 & 55900,00 & 60300,00 & 77200,00 & 78800,00 \\
\hline Estimated commission ( in mln PLN) & 647,68 & 715,52 & 771,84 & 988,16 & 1008,64 \\
\hline
\end{tabular}

Source: own research based on the Polish Financial Supervision Authority.

Assuming an estimated average commission amount in the banking sector at $1.28 \%$ of the amount of guarantees provided, it can be estimated that its total amount for the years 2011-2015 fluctuated between PLN $650 \mathrm{mln}$, and 1 bln on a yearly basis.

\section{Insurance guarantees in the risk management process}

The pursuit of profit maximization in companies has necessitated the need for "risk technology" as a professional, planned and organized diagnosis and countermeasure for losses arising from the realization of risk. It is important to be able to define it in terms of size and to determine its impact on the functioning of an enterprise using economic, legal and statistical knowledge. As a result, this process, called risk management, is not a collection of acts ad hoc but a systematic effort to secure the company's assets so that its objectives can be achieved without distortions. The proper way of risk assessment is of particular importance because managers on this basis are able to take remedial measures that minimize them. The negative and positive effects of risk are the incentives for an organization to take steps to both minimize its costs and maximize its benefits. It is, therefore, essential to safeguard the company's security-cost goals, leading to the creation of a security system that would maximize the value of the business [Harington, Niehaus 1999]. 
Insurance guarantees play an important role in this process, which at the same time provides protection for both the principals and their beneficiaries by securing their credibility. Their use for both parties involved is important in the process of improving the financial performance of businesses by maximizing risk mitigation whilst safeguarding against the consequences of its implementation, especially for the beneficiaries. This is characterized by a single risk assessment because it is not possible to estimate statistically the likelihood of a claim due to significant fluctuations in claims, no change in the level of risk during the guarantee period, long guarantee period, high guarantor liability and individual damages of maximum height. Therefore, the activity of issuing a guarantee is always assessed as highly risky. This is due to the specificity of the guarantee, which is a very strict guarantor obligation. Therefore, the guarantor and the obligee are "linked" in the case of a guarantee by the special highest trust to the extent that is not the case with other types of insurance. It is unacceptable for a claimant to guarantee certain information before they issue a guarantee or refuse to provide certain information in a secretive manner. Due to the specific nature of the guarantee, its irrevocability must at all stages of co-operation be acceptable to the guarantor's risk monitoring conditions, including:

- periodical control of legal and financial situation,

- monitoring the implementation of contractual obligations guaranteed by the guarantee,

- monitoring the status and value of collateral established for the guarantor.

The purpose of the above activities is to be aware of risk control, preferably with the support of the guarantor. This results in the creation of possible reserves, taking

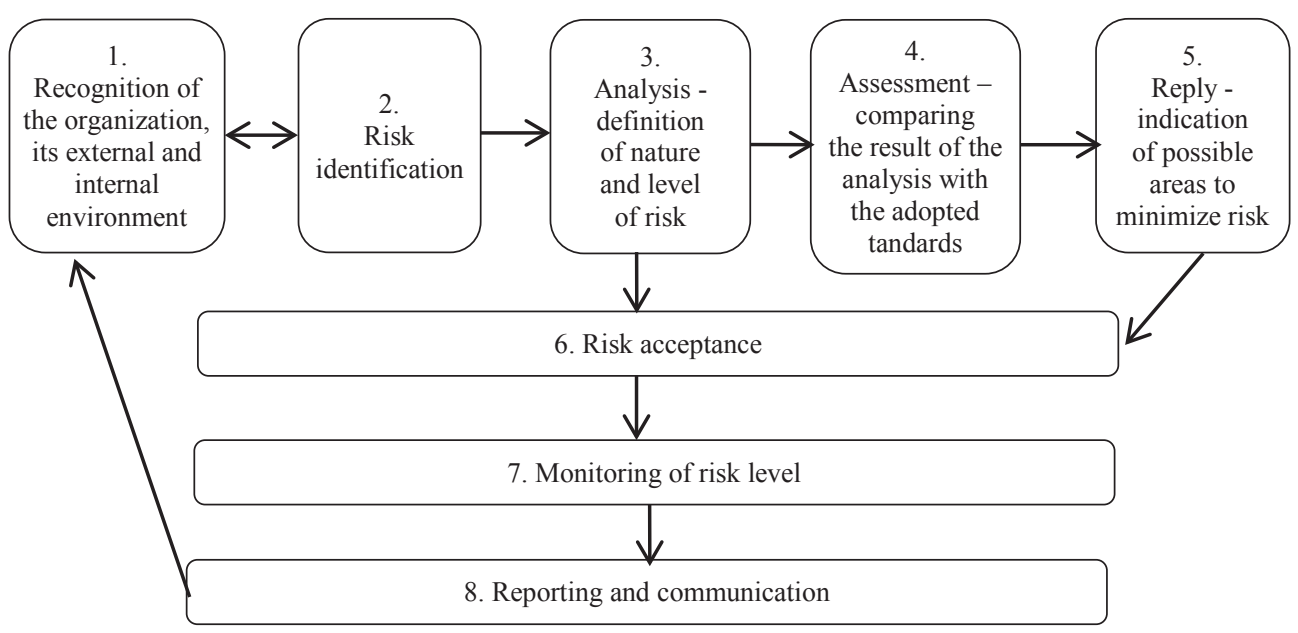

Fig. 2. Areas of analysis in the risk management process of the insurance guarantee

Source: own research based on [Enterprise Risk Management Program... 2012, p. 1]. 
measures to discipline the obligee, preparing for debt collection of receivables in case of the need to pay the guarantee sum. The areas of analysis in the insurance risk management process are presented in Figure 2.

The rule is that guarantees can only be provided with the so-called "zero risk principle", i.e. only if the risk assessment is fully believed that there will be no payout at the request of the beneficiary. Hence, the need for an individual approach to the risks arising from the granting of the requested guarantee. Each case is a combination of a number of elements including: the guarantee obligation, the claimant, the liability of the guarantee text, the sum and duration of the guarantee, the ability to perform the obligation and the security of the guarantor's claims. The prerequisite for a positive final risk assessment of the claimed guarantee is its positive result in all areas tested, and a single negative result means in principle a refusal to issue a guarantee [Kukiełka, Poniewierka 2003].

\section{The role and importance of insurance guarantees in enterprises in the light of own research}

In order to obtain empirical data on the role and significance of insurance guarantees, a pilot study was conducted using a questionnaire and a direct interview was applied as a follow-up technique. The survey was the most effective form of data collection, often inaccessible in other ways. Their use was explained by the ability to clarify the possible complexities of the wording and the speed of data acquisition. The purpose of the study was to identify motivations and criteria, as well as to identify the factors determining the decision to use insurance guarantees in enterprises. The surveyed population comprised 147 companies, among them 14.3\% small ones, (72.8\%) medium and (12.9\%) large, which responded to the questionnaire between January and March 2017.

The results obtained revealed that there was a great diversity among the surveyed entities regarding the role and importance of insurance guarantees as a tool supporting the management processes in enterprises. Of the respondents, just over $87 \%$ declared that they knew the insurance companies' offer for insurance guarantees, while insurance intermediaries were the key source of information. The vast majority of respondents pointed out that success was conditioned by safety, so an active, conscious and thoughtful attitude to risk was needed, and the right way to evaluate was particularly important.

The results of the survey indicated that nearly $79 \%$ of respondents used insurance companies offering insurance guarantees over the past three years. For over $57 \%$ the purchase of the insurance guarantee was the result of the expectations of the counterparties the respondents cooperated with, about $43 \%$ of the respondents independently decided to buy the guarantee, which was one of the alternative methods of hedging, as expected by the beneficiaries of the guarantee. In the case of 34 respondents $(23.1 \%)$, the respondents pointed out that obtaining the guarantee 
was problematic, and 10 entities $(6.8 \%)$, despite their interest, were not able to meet their expectation.

The insurer's offer for insurance guarantees was primarily concerned with medium-sized companies, followed by small and large ones. Respondents most often pointed to the requirements imposed by market participants, then the law and financial possibilities. At the same time the results of the survey indicated that for nearly $37 \%$ of the respondents, insufficient ability to take advantage of insurers' offers for insurance guarantees would cause serious financial and organizational problems in the area of their activity.

\section{Conclusion}

The implementation of the adopted strategies forces enterprise managers to use tools aimed at minimizing risk. They include, among others, insurance guarantees whose importance is constantly increasing. Due to the high degree of complexity, the link with economic and political processes and the strong dependence on business cycle fluctuations in the economy, any attempts to assess their role and importance in risk management processes in a single, individual case should take these elements into account. The availability of the offer often depends on the positive assessment of the risk by the insurance company providing the guarantee. The risk assessment process associated with granting a guarantee is primarily to examine the customer's current ability to settle liabilities and forecast this capability over the guaranteed period. The potential and preparation of the obligee to perform the task specified in the basic agreement and the liquidation value of the enterprise taking into account debt recovery possibilities are also assess.

\section{Bibliography}

Andrzejuk B., Heropolitańska I., 2007, Gwarancje bankowe i ubezpieczeniowe, Wolters Kluwer, Warszawa, p. 136.

Chauffour J.P., Saborowski Ch., Soylemezoglu A.I., 2011, Should developing countries establish export credit agencies?, [in:], Chauffour J.P., Malouche M. (eds.), Trade finance during the Great Trade Collapse, The World Bank, Washington D.C., pp. 274-275.

Dankiewicz R., 2005, Możliwości finansowe przedsiębiorstw a gwarancje ubezpieczeniowe, [in:] Czekaj J. (ed.), Kapitat i źrodła jego pozyskiwania dla przedsiębiorstw i regionów, Wydawnictwo Wyższej Szkoły Bankowości i Finansów w Bielsku Białej, Bielsko Biała, p. 635.

Dankiewicz R., Kaczmarczyk P., Kidacka M., 2017, Gwarancja ubezpieczeniowa w postępowaniu upadłościowym, [in:] Dankiewicz R., Ostrowska-Dankiewicz A. (eds.), Ubezpieczenia w procesie zarządzania ryzykiem podmiotów gospodarczych, OW Politechniki Rzeszowskiej, Rzeszów, p. 117.

Enterprise Risk Management Program, Guide to Risk Assessment \& Response, The University of Vermont 2012, p. 1. 
Gurgul S., 2014, Instytucja gwarancji ubezpieczeniowej w postępowaniu upadłościowym stron stosunku gwarancji, Monitor Prawniczy, nr 3, p. 125.

Harington S., Niehaus G., 1999, Risk Management and Insurance, Irwin/McGraw-Hill, Boston, p. 4.

Holly R. (ed.), 2003, Ubezpieczenia finansowe i gwarancje ubezpieczeniowe, Poltext, Warszawa, p. 81. Jańska A., 2013, Ocena ryzyka w procesie udzielania ubezpieczeniowych gwarancji kontraktowych, Copernican Journal of Finance \& Accounting, vol. 2, Uniwersytet Mikołaja Kopernika w Toruniu, Toruń, p. 94.

Kukiełka J., Poniewierka D., 2003, Ubezpieczenia finansowe, OW Branta, Bydgoszcz-Warszawa, p. 69 , 185.

Poniewierka D., 1997, Ocena zakładu ubezpieczeń jako gwaranta, Wiadomości Ubezpieczeniowe, nr 11/12, s. 43.

Schmidt P., Surety Survey 2016, 2017, Global Credit \& Surety Reinsurance, pp. 10-16.

The act of 23 April 1964 Civil Code, Journal of Laws No. 1964, no. 16, item 93 as amended. 